\title{
TRIPARTISM AS THE FACTOR OF DEVELOPMENT OF THE HIGHER SCHOOL (BYTHE EXAMPLE OF THE VOLGA STATE UNIVERSITY OF TECHNOLOGY)
}

\author{
Evgenii Romanov* \\ Volga State University of Technology, Russian Federation \\ Yurii Andrianov \\ Volga State University of Technology, Russian Federation \\ Lyudmila Nizova \\ Volga State University of Technology, Russian Federation \\ Tatyana Sannikova \\ Volga State University of Technology, Russian Federation
}

The role of the International Labour Organization as the center of social partnership with the reasoning of Conventions and Recommendations, development of tripartism in the countries of Europe, the USA and Japan is revealed. By the example of genesis of partner relations in the Russian Federation, the authors describe institutional environment including formal and informal institutes under conditions of economic, social, legal, political and demographic factors influencing them. On the basis of monitoring, the priorities of positive influence of social partnership on the development of the sphere of education and science, both on republican, and on corporate levels are determined. Higher school became a special area of research, the Volga State University of Technology, as its representative member, bases its pioneering work on a versatile activity of the Guardian council. Significant proof of the efficiency of its influence is training and employment of the engineering staff.

Key words: Social partnership, State, Employers, Employees, Higher school, Guardian council, Guality of life, Institutional environment, Tripartism

\section{INTRODUCTION}

The global center of social partnership is, as it is known, the International Labour Organization (ILO) created in 1919. Its purpose is to establish and preserve the social world, regulate social and labour relations, protect human rights. It became one of the most representative and authoritative international organizations; it is awarded with the Nobel Peace Prize.

The International Labour Organization influences greatly formation and regulation of labour, social, economic, and professional relations. The directions of its activity are determined in the basic documents: the Charter [03] and Philadelphian declaration [10], 180 conventions and 190 recommendations [01].

The concept of 'social partnership' has come into scientific use, theory and practice of regulation of social and labour relations rather recently. In the world community, it began to develop after the Second World War, and was finally generated in 1960s-1970s, while it is only being formed in the Russian Federation (RF). Nowadays the most advanced system of social partnership is characteristic of such European countries as Germany, Austria, Sweden and others. To a lesser degree it is developed in the countries of Southern Europe, the USA, and Japan. The systems of social partnership do not exist in underdeveloped countries.

Opinions of the ILO experts testify to the importance of social dialogue: S. Glovatskas says, 'Priorities of the ILO Labour Group and the ILO Bureau on the Activity of Workers take into account the global situation characterized by deepening of the global financial and economic crisis' [02], and as V.Mokanu states it, there exist two kinds of social dialogue: bilateral one, between representatives of employers and employees, 
and tripartite one with the participation of the state [07]. Their role is revealed, first of all, on the quality of life of the population.

As stated above, the conventions and recommendations of the ILO play an important part in the development of social partnership. Many of them are ratified in the Russian Federation and have underlain legal base on the issues of work and employment of the population. They are reflected in the Constitution of the Russian Federation [11], the Labour Code of the Russian Federation [06], the law On education in the Russian Federation, etc.

In Russia the concept of 'social partnership' has come into legal use from the moment of acceptance of the Decree of the President of the Russian Federation No 212On social partnership and settling grievance (conflicts)of 15November 1991 [09] and the Federal law No 92-Ф3of1May 1999On the Russian tripartite commission on settling social and labour relations.

However the official legal concept 'social partnership' is fixed at the federal legislation level in the Labour code of the Russian Federation for the first time. In section II, 'social partnership in labour sphere'is given for the first time and is defined as follows: 'social partnership is the system of mutual relations between employees (representatives of employees), employers (representatives of employers), bodies of the government, and local government bodies directed at maintaining the coordination of the interests of employees and employers on the issues of labour relations regulation and other relations directly connected to them' [06, item 23].

With a view of coordinating the actions of the parties concerned we have generated institutional environment of social partnership. Factors influencing social partnership are economic, social, legal, political, demographic ones. The mechanism of interaction of formal and informal institutes, bodies and organizations interested in the development of social partnership is formed under their influence [08]. Formal institutes are acts, state institutes and the system of their management, employers of all patterns of ownership and intermediary organizations representing interests of employees (trade unions, tripartite commissions, commissions on labour disputes, etc.) as well as public organizations (youth, disabled people and veteran organizations, etc.) (Figure 1).

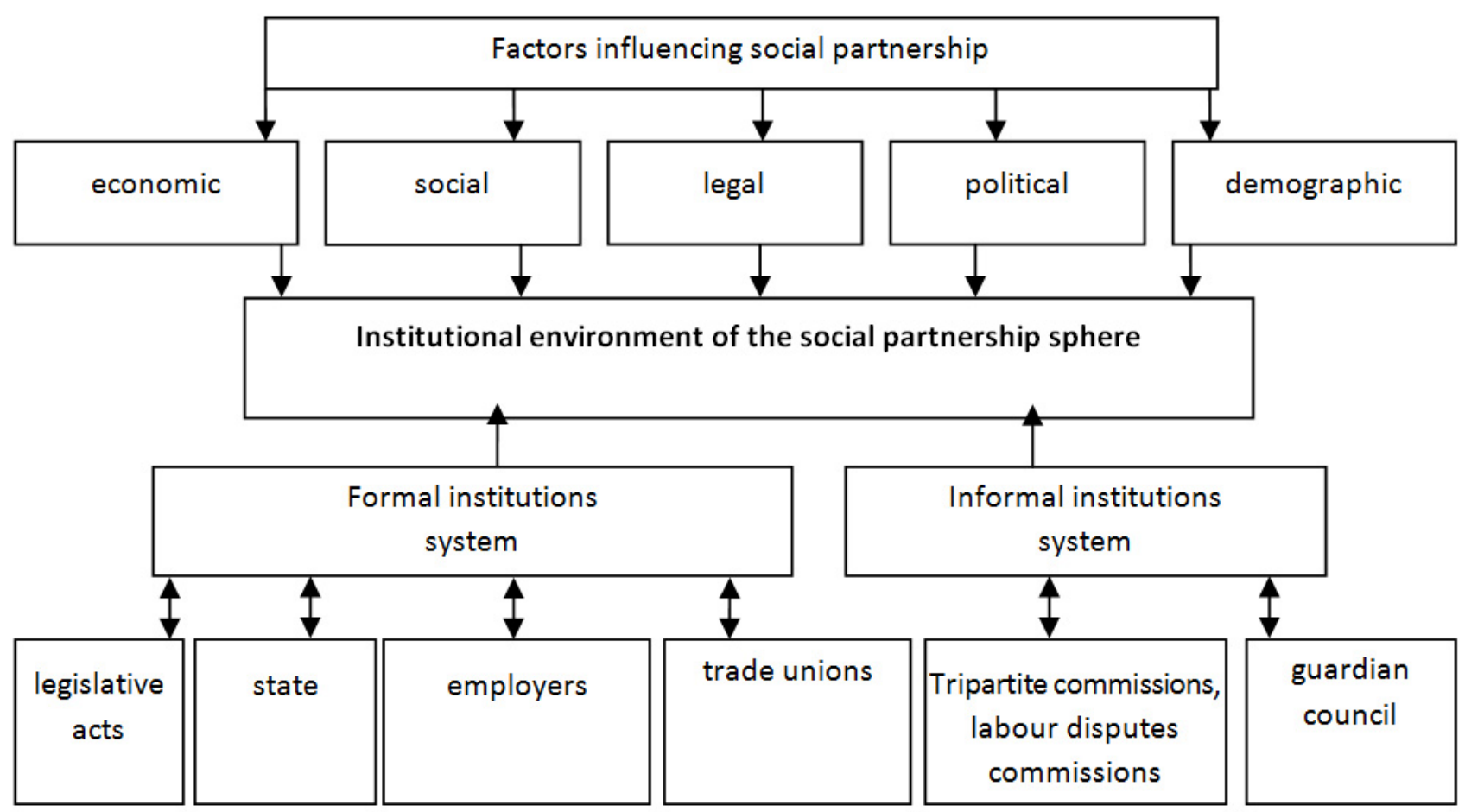

Figure 1: General constituent elements of the institutional environment in the sphere of social partnership 


\section{RESEARCH RESULTS}

The institutional environment suggested by the authors is of special importance on national, mesoeconomic, municipal and corporate levels. So, the General agreement between the all-Russia associations of trade unions, the all-Russia associations of employers and the Government of the Russian Federation is made for the period of 2014-2016 on the basis of formal institutes. In the Republic of Mari El the Republican tripartite commission for regulation of social and labour relations has been functioning since1999. It makes the Republican tripartite agreement between the
Government of Republic of Mari El, Association of the organizations of trade unions of the Republic of Mary Eland the republican association of employers. Besides, 18 republican sectoral, 17 territorial, 25 sectoral(at the level of municipal formations) and 6 other agreements are made.

For budgetary sphere a priority direction is realization of the Decree of the President of the Russian Federation No 597 of 7May 2012Onthe actions on realization of the state social policy contemplating stage-by-stage bringing of the level of average salaries in education of the Republic of Mari El to the average republican level (Figure 2).

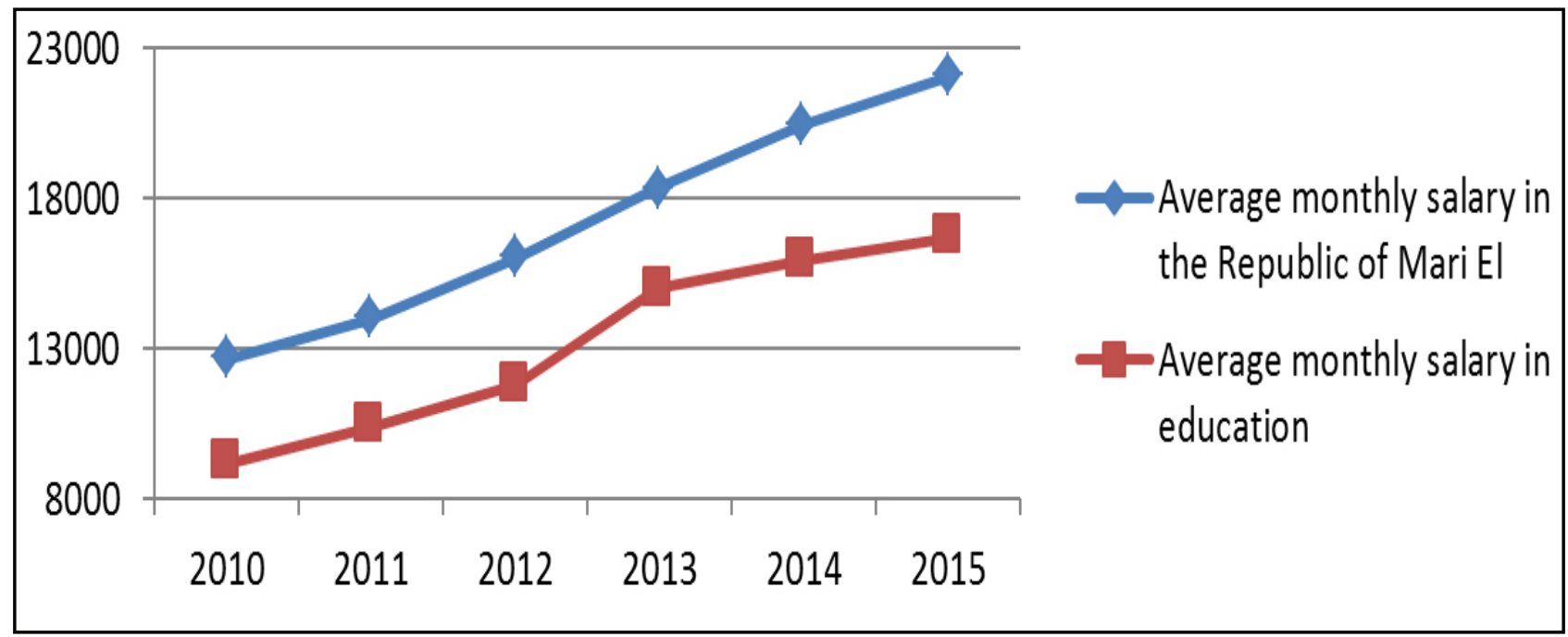

Figure 2.Dynamics of average salary in the Republic of Mari El and in the sector of education, rbs

Increased interest to the development of social partnership is dictated by presence of painful points in social and labour sphere: essential gap between cost and price of labour; absence of the forecast of manpower balance for different spheres of activity for the foreseeable future and for the long run; discrepancy of the market of educational services and the requirements of labour market.

Therefore it is not a coincidence that in recent year sparticular importance has been given to social partnership in the sphere of education. The Mari republican organization of Education and Science Employees Union of the Russian Federation declared 2015 the year of effective social partnership. Under the initiative of the chairman of the republican committee of the organization mentioned, L.V. Purtova, a lot of meetings, colloquiums, scientific and practical conferences, seminars were held with social partners at mezoeconomic and municipal levels. This was also reflected in the activity of corporate pri- mary organizations of the higher school and the Volga State University of Technology(VSUT), in particular.

A vivid example of the role of social partnership in educational process is the Guardian council of the VSUT. It was created in 2002 by the decision of the Conference of graduates. It is headed by N.I. Kuklin, Deputy Head of the government of the Republic of Mari El, the graduate of the faculty of building engineering. The Vice President of the Guardian council is VSUT rector, E.M. Romanov [04].More than 30 graduates of the VSUT are the members of the council, who are heads of enterprises, businessmen and public men. An overall objective of functioning of the Guardian council is assistance in the VSUT development and formatting it as a center fortraining highly skilled experts, professionals capable to solve problems of fundamental and applied character at an up-to-date level. Its basic forms of activity are: 
1) gaining practical skills by students via the development of mentoring, taking professional practice, training and excursions at the enterprises of the council members;

2 ) creation of small joint innovative enterprises and employment of the graduates of the University;

3) raising organizational and financial resources to open lecture rooms, laboratories, purchase multimedia equipment for interactive forms of training;

In accordance with the aim stated the Guardian council solves the following problems:

- assistance in VSUT functioning as a center of education, science and culture;

- strengthening financial, information and material and technical base of the University;

- rendering material, organizational and methodical assistance to learning-teaching process perfection;

- social protection of students, teaching staff and employees;

- support of initiatives of scientific intelligentsia representatives, various funds and organizations on creation of conditions for the development of the University as a whole and its structural divisions;

- revealing especially gifted students and rendering them all-round aid for disclosing their abilities and talent;

- assistance to development of versatile cooperation, including international, within the framework of scientific, educational and research activity;

- stimulation of fundamental and applied sciences development; dissemination of the results of scientific, practical and other public work of the University collective members;

- assistance in the account of national economy needs in experts and definition of new directions of their training and retraining on the programs the University specializes in;

- realization of charities within the framework of assistance to spiritual development of the person.

Such university actions as the Day of the graduates, New Year tournament, Christmas ball, the University Birthday, the Fresher's Day are conducted under the aegis of the Guardian council annually.
Members of the Guardian council participate personally in scientific and research work of the University. For example, the Head of municipal formation 'Medvedevski municipal area', the Chairman of the Assembly of Deputies, Candidate of Economics D.G. Shagiakhmetov acts as a reader of Master's Degree students' dissertations. G.S. Nikitin, Director General of scientific and production company "Geniks", Dr.h.c. of the VSUT makes great contribution to educational process; he has founded nominal grants for students, helped with equipping several laboratories for "Bioenergy", the Center of engineering and industrial design in wood complex and energetics. All trustees accept active participation in many projects of the University, helping it to grow and develop, providing necessary relationship with production sector and stimulating research activity. They sponsor the events on the scale of the University, its institutes and faculties, found nominal grants and scholarships, open equipped nominal lecture halls. This year a unique for Mari El museum of Volgatech graduates will be opened with participation of the members of the Guardian council. It will be devoted to the achievements of working dynasties whose destinies in due time crossed with the University, as well as to the 50thanniversary of students construction brigades movement in the Republic of Mari El[04].

Members of the Guardian council render great support in realization of the Federal program New staff of the military-industrial complex. In conformity with the decree of the Government of the Russian Federation No. 192 of 15March 2015 ,the strategy of creation of the system of multilevel continuous training with a view of vocational training of the staff with secondary and higher education is successfully implemented. For the last three years, within the framework of realization of this project, about 400 engineering staff members were trained for the benefit of such enterprises as Mari machine-building factory, JSC; Technotech, LLC; Oktyabr' Industrial Group, FSUE in Kamensk-Uralsky; Volga electromechanical factory, JSC; the Russian Federal Nuclear Center in Sarov; the Kazan aviation factory named after S.P. Gorbunov - TUPOLEVPJSC Branch. Thanks to the Guardian council a positive factor of $100 \%$ level of the state task fulfillment in view of student body retention, positive dynamics of students' progress and $85 \%$ employment of graduates at the enterprises of the 
military-industrial complex are marked.

Implementation of the program of strategic cooperation of the VSTU and Mari machine-building factory, JSC is a true argument of the importance of social partnership for the higher school. This town-forming enterprise makes competitive world-class products. Branches of three chairs (Radio Engineering and Communication, Information Safety, Machine-building and Materials Science) operate at the plant. Dual training is practiced: annually up to 80 undergraduate students, combining study with work at the plant, get practical experience and apply their knowledge in manufacturing environment. As a result, a unique Center of radar-tracking systems and complexes, promoting application of theoretical knowledge of the graduates in practice [05], is created at the plant. Realization of 25 unique educational programs is carried out on its base.

The above-stated practice of social partnership of the Guardian and the Scientific council promotes satisfactory decision of such a challenge as employment of the VSUT graduates (Figure 3).

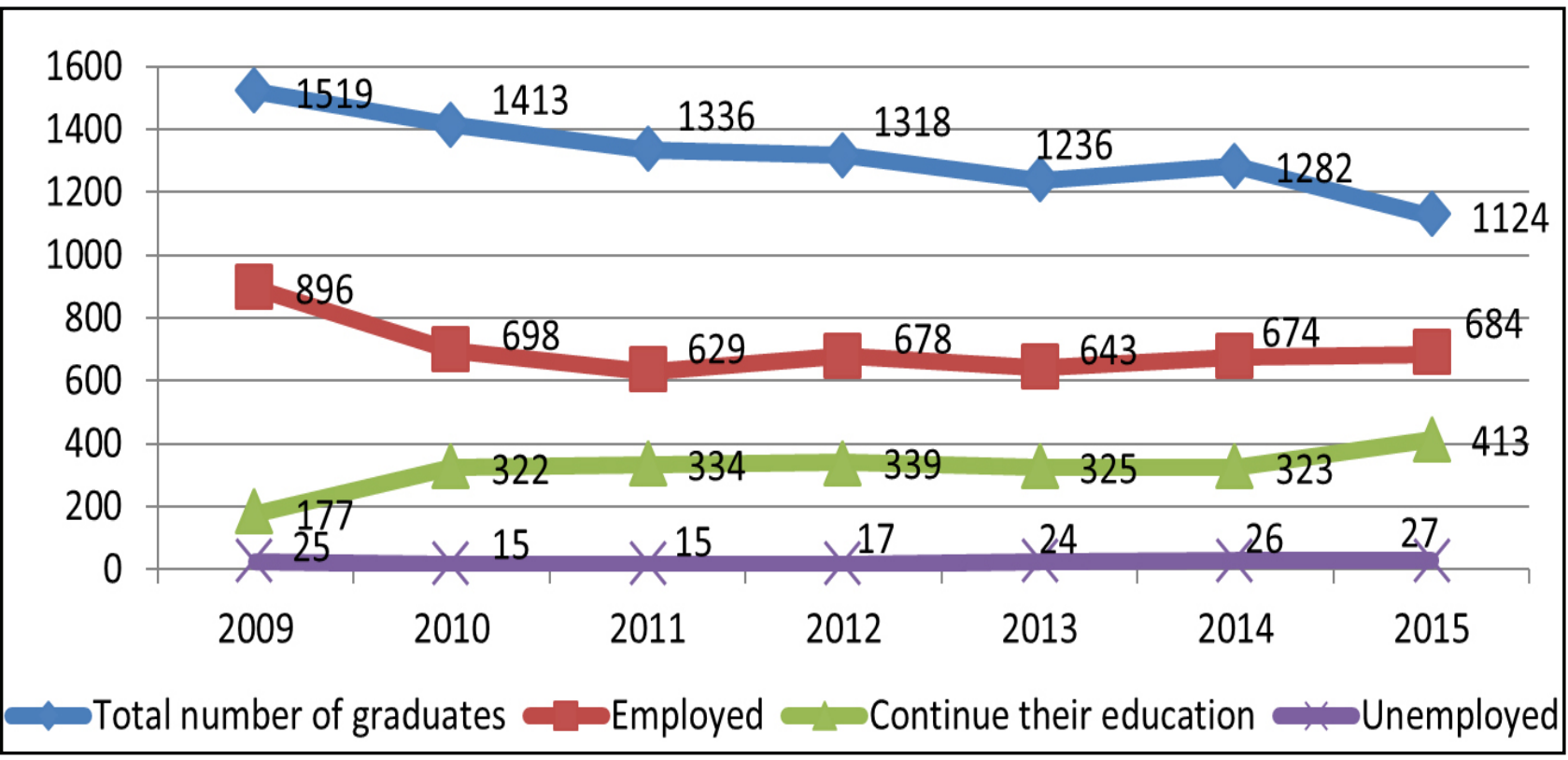

Figure3.Dynamics of graduates' employment, persons

The dynamics shows that almost $80 \%$ of graduates work in the specialty or continue training in magistracy.

\section{CONCLUSIONS}

Thus, during a short period of the Guardian council work a new structure of the social partnership has been created designed to render all-round support to the development of higher education in the Republic of Mari El. Trustees participate actively in many VSUT projects, provide necessary communication with the production sector and stimulate scientific and research activity of the University. The Guardian council faces new tasks directed at the implementation of a strategic aim of the VSUT development, i.e. becoming one of the Russian leading scientific and educational complex of innovative type.

\section{AKNOWLEDGMENT}

The reported study was funded by the Ministry of Education and Science of the Russian Federation (No. 5.8394.2017/8.9).

\section{REFERENCES}

1) Convention and recommendation sadopted by ILO. V. 1-2.- Geneva, 1991.[Electronic resource]. URL: http://www.ilo.org/ilohex/Nussian/docs

2) Glovatskas,S. Priorities in the work of the group of workers and ILO's Bureau for Workers' Activities (ACTRAV) // For worthy work and social justice. Materials of the International scientific and practical conference of General confederation of trade unions. Moscow: Profizdat, 2014. - Pp.32-37

3) International Labour Organisation Charterand International Labour Conference regulations. 
- Geneva, 1988. [Electronic resource]. URL: http://www/ilo.org/ilohex/Nissan/docs

4) It is impossible to change the place of a meeting. The Engineer, VSUT. -No. 5 of 2 June 2016.

5) Journal of Applied Engineering Science. ENGINEERING PERSONNEL TRAINING THROUGH THE EXAMPLE OF VOLGA STATE UNUVERSITY OF TECHNOLOGY Vol. 1, (2016).

6) Labour Code of the Russian Federation. - Moscow: Prospect, 2016. - 256p.

7) Mokanu, V. Social dialogue as a basis of a Worthy work policy // International scientific and practical conference by Federation of Independent Trade Unions of Russia - International Labour Organisation in Privolzhskiy Federal DistrictRole of trade unions in promotion of standards of Worthy work: Proceedings of the international scientific and practical conference.-Orenburg: Expresspechyat', 2014. -Pp. 26-29

8) Nizova, L.M. Social partnership in the sphere of employment of population: monograph/
L.M.Nizova. - Yoshkar Ola:MSU, 2012. - 264p.

9) On social partnership and settling grievance (conflicts): the Decree of the President of the RFNo. 212 of 15.11.1991// Vedomosti ofCPDand SSRSFSR. - 1991 -No.47. Item 1611.

10) Philadelphian Declaration Onthegoals and aimsof ILO (1947) [Electronic resource]. URL: $\quad$ http://www/ilo.org/public/russian/region/eurpro/moscow/

11) The Constitution of the Russian Federation: (Publ. with the amendments to the Law on Amendments to the Constitution of the Russian Federation on December 5, 2008 No. 6 Federal Constitutional Law of December 30, 2008 No. 7, Federal Constitutional Law of February 5, 2014 No. 2. Federal Constitutional Law of July 21, 2014 No.11 Federal Constitutional Law of February). Ros.Gou, 2015, July 20 .

Paper sent to revision: 16.01.2016.

Paper ready for publication: 06.07.2017. 